\title{
Conservation and the rights of Indigenous peoples and local communities: looking forwards
}

\author{
Stephanie Brittain, Helen Tugendhat \\ Helen Newing and E.J. Milner-Gulland
}

As the world looks forwards to a vision of living in harmony with nature by 2050 (CBD, 2019), we can learn much by tracing the path that conservation science and practice have taken as we grapple with how the ownership, use and access rights of Indigenous peoples and local communities intersect with conservation. Oryx is a treasure trove in this respect, with a history of discourse on this topic. Its archives reveal pivotal moments that have contributed to an overarching move within conservation policy towards more sustained attention to human rights. Here we look back through the Oryx archives, to stimulate reflection on how conservation has engaged with human rights, how that has intersected with evolving global policy, and what we can learn from this history to ensure that human rights are better understood and placed at the centre of conservation policy and practice.

The pages of Oryx during the 1960s and 1970s reveal a strong focus on a purely environmental imperative for conservation, with little tolerance of the presence of local people in protected areas. For example, Curry-Lindahl $(1975$, p. 82) stated explicitly 'that National Parks and equivalent reserves must be protected against all human exploitation'. Other articles from this period note population growth as a key driver of the need for strictly protected areas to safeguard against human-caused degradation (Bertram, 1963; Worthington, 1965).

However, articles from the 1990 os and 2000 s illustrate a shift towards community-based approaches and consideration of human well-being. Horwich (1990) and Adams \& Thomas (1996) documented early examples of communitybased approaches, and Stearman \& Redford (1995, p. 29) described how land was returned to, and successfully protected by, Indigenous peoples in Bolivia, although they present the recognition of land rights as instrumental ('to enable the Yuqui [people] to exploit game animals sustainably and to defend their lands') rather than as a legal and moral obligation. Hutton \& Leader-Williams (2003, p. 215) argued that 'sustainable use and incentive-driven conservation should both be at the centre of the conservation agenda this

Stephanie Brittain (10 orcid.org/0000-0002-7865-0391), Helen Newing* (ㄷ) orcid.org/0000-0002-4710-1824) and E.J. Milner-Gulland (ㅁ) orcid.org/ 0000-0003-0324-2710) The University of Oxford, Oxford, UK

E-mail stephanie.brittain@zoo.ox.ac.uk

Helen Tugendhat Forest Peoples Programme, Moreton-in-Marsh, UK

${ }^{*}$ Also at: Forest Peoples Programme, Moreton-in-Marsh, UK century'. Western (2001, p. 202) supported this view, pointing out that 'these are not the views of weak-kneed conservationists, but of experienced protectionists too...Where once parks were planned against people, the World Commission on Protected Areas now advocates they be planned with local people'.

However, there was by no means a consensus on community-based approaches to conservation: there was also a pushback, which became known as the back to barriers movement (Hutton et al., 2005). For example, Oates (1995) called for increased funding for protection of wildlife through enforcement, using a case of the unintended consequences of an integrated conservation and development project as supporting evidence. In a wider debate about the traditional vs new conservation approaches, and about who has legitimate rights, Spinage (1998, p. 273) provided the memorable line: 'claims that denial of indigenous peoples' land rights is contrary to both customary and international law may conform to present-day western ethics of Homo sapiens, but in nature there is only one law of possession and that is the law of occupation by force'. In his response Colchester (1998) questioned the morality of this approach and asked how long protected areas managed in such a way could survive.

In the following 10 years there was a substantial shift in international policy towards more inclusive approaches (Newing \& Perram, 2019), but more recently there has been an increasing polarization of positions, resulting in a marked divergence within the conservation community between a protectionist wing and those who argue that engaging with people is not only effective, but both morally right and legally obligatory. The Half-Earth debate in Oryx and elsewhere is an example of such a polarization. Half-Earth is a call for $50 \%$ of the planet to be protected by 2050 , especially areas of high biodiversity value, which in many cases are where Indigenous peoples and local communities live. Büscher et al. (2017a,b) questioned whether the idea of turning half the Earth into a network of protected areas is feasible or just, and the condescending nature of the statement that 'local communities should be actively involved in conservation efforts' (Cafaro et al., 2017, p. 400). Following a series of articles debating the implications of the Half-Earth proposal for the rights of Indigenous peoples and local communities, the Half-Earth project has moved towards greater recognition of the contributions of Indigenous peoples and local communities to conservation. 
However, human rights should not be an afterthought, and concerns remain about the extent to which the Half-Earth project will ensure protection and fulfilment of the rights of Indigenous peoples and local communities.

Thus, over the past 60 years, despite significant advances in acknowledgement of the rights of Indigenous peoples and local communities in global conservation policy, a more fragmented picture is apparent in the pages of Oryx. Publications about community involvement in empirical case studies have focused mainly on instrumental arguments about the biodiversity outcomes of involving communities as partners; discussions of rights have been discussed principally in editorials and other opinion pieces. Meanwhile, widespread rights abuses in the name of conservation have continued.

As we look towards 2050, it is time that human rights obligations are brought to the fore of conservation research and action rather than viewed as optional or simply as a means to achieve conservation goals. One essential step towards this is for conservationists to embrace international human rights law and policy commitments and 'ensure that conservation actions are not only effective, but also compatible with international law and morally responsible' (Newing \& Perram, 2019, p. 596). This suggestion was mirrored in 2021 in an Open Letter to all States from the UN Special Rapporteur on human rights and the environment, which stated that 'a rights-based approach to conservation is an obligation, not an option, because of the international human rights commitments made by all States' (Boyd, 2021, p. 2). Thus ultimately the management and establishment of protected areas in full compliance with the rights of Indigenous peoples and local communities requires these rights to be acknowledged and reflected in national laws, and working towards this is a task that conservationists continue to face today.

In finishing, it is relevant to turn to procedural rights, which include the right to inclusion and participation in decision-making. To fulfil these rights for Indigenous peoples and local communities, they must have the opportunity, where desired, to present their own case studies and opinion pieces in the various fora that contribute to evolving discourses in conservation and to decision-making on policy and practice, including academic journals. This will require more flexibility from journal editors and reviewers and more innovative approaches from researchers towards collaborative research and co-authorship. In response to this need, this retrospective virtual issue will be followed in due course by a special theme in Oryx on conservation and human rights, predominantly comprising articles by Indigenous authors. The special theme will aim to advance and nuance current discussions about the relationship between conservation and human rights, both in terms of how to improve recognition of rights in conservation and also in terms of how this can facilitate effective conservation.

This Editorial and the Oryx articles cited herein are freely available as a virtual issue of the journal at cambridge.org/ core/journals/oryx/virtual-issues.

\section{References}

Adams, W. \& Thomas, D. (1996) Conservation and sustainable resource use in the Hadejia-Jama'are Valley, Nigeria. Oryx, 30, 131-142.

Bertram, C. (1963) Man Pressure. Oryx, 7, 97-101.

Boyd, D. (2017) Mandate of the Special Rapporteur on the Issue of Human Rights Obligations Relating to the Enjoyment of a Safe, Clean, Healthy and Sustainable Environment. Open Letter to all Permanent Missions to the United Nations Office at Geneva. 21 January 2021, United Nations Human Rights Special Procedures, Geneva, Switzerland. ohchr.org/Documents/Issues/Environment/ SREnvironment/Geneva-Climate-Nature-en.pdf [accessed 12 July 2021].

Büscher, B., Fletcher, R., Brockington, D., Sandbrook, C., Adams, W.M., CAmpBell, L. et al. (2017a) Half-Earth or Whole Earth? Radical ideas for conservation, and their implications. Oryx, 51, 407-410.

Búscher, B., Fletcher, R., Brockington, D., Sandbrook, C., Adams, B., Campbell, L. et al. (2017b) Doing Whole Earth justice: a reply to Cafaro et al. Oryx, 51, 401-401.

Cafaro, P., Butler, T., Crist, E., Cryer, P., Dinerstein, E., Kopnina, H. et al. (2017) If we want a whole Earth, nature needs half: A response to Büscher et al. Oryx, 51, 400-400.

Colchester, M. (1998) Who will garrison the fortress? A reply to Spinage. Oryx, 34, 245-248.

CBD (Convention on Biological Diversity) (2019) Post-2020 Global Biodiversity Framework: Discussion Paper. Notes by the Executive Secretary. CBD/POST2020/PREP/1/1. 25 January 2019.

CURry-Lindahl, K. (1975) National parks-their role in the modern world. Oryx, 13, 77-84.

Horwich, R.H. (1990) How to develop a community sanctuary - an experimental approach to the conservation of private lands. Oryx, 24, 95-102.

Hutton, J., Adams, W.M. \& Murombedzi, J.C. (2005) Back to the barriers? Changing narratives in biodiversity conservation. Forum for Development Studies, 32, 341-370.

Hutton, J. \& Leader-Williams, N. (2003) Sustainable use and incentive-driven conservation: realigning human and conservation interests. Oryx, 37, 215-226.

Newing, H. \& Perram, A. (2019) What do you know about conservation and human rights? Oryx, 53, 595-596.

OAtes, J. (1995) The dangers of conservation by rural developmenta case-study from the forests of Nigeria. Oryx, 29, 115-122.

SPINAGE, C. (1998) Social change and conservation misrepresentation in Africa. Oryx, 32, 265-276.

Stearman, A. \& Redford, K. (1995) Game management and cultural survival: the Yuquí Ethnodevelopment Project in lowland Bolivia. Oryx, 29, 29-34.

Western, D. (2001) Taking the broad view of conservationa response to Adams and Hulme. Oryx, 35, 201-203.

Worthington, E. (1965) Can the Earth support us all? Oryx, 8, 25-27. 